\title{
Relevance of hemostatic risk factors on coronary morphology in patients with diabetes mellitus type 2
}

\author{
Thomas W Jax*1,2,3, Ansgar J Peters ${ }^{3}$, Gunnar Plehn ${ }^{4}$ and Frank- \\ Chris Schoebel ${ }^{3}$
}

\begin{abstract}
Address: ${ }^{1}$ Profil Institut für Stoffwechselforschung, Division of Cardiometabolic Research, Hellersbergstrasse 9, 41460 Neuss, Germany, ${ }^{2}$ Klinik für Kardiologie, Herzzentrum Wuppertal, Universität Witten-Herdecke, Wuppertal, Germany, ${ }^{3}$ Medizinische Klinik und Poliklinik B (Internal Medicine), Department of Cardiology, Pneumology and Angiology, Heinrich-Heine-University, Düsseldorf, Germany and ${ }^{4}$ Klinik für Kardiologie, Marienhospital Herne, Herne, Germany

Email: Thomas W Jax* - thomas.jax@profil-research.de; Ansgar J Peters - ap@kardiologiekoeln.de; Gunnar Plehn - gplehn@gmx.de; FrankChris Schoebel - schoebel@cardiopraxis.de

* Corresponding author
\end{abstract}

\section{Published: 6 May 2009}

Cardiovascular Diabetology 2009, 8:24 doi:10.1/86/1475-2840-8-24

This article is available from: http://www.cardiab.com/content/8/I/24

(C) 2009 Jax et al; licensee BioMed Central Ltd.

This is an Open Access article distributed under the terms of the Creative Commons Attribution License (http://creativecommons.org/licenses/by/2.0), which permits unrestricted use, distribution, and reproduction in any medium, provided the original work is properly cited.
Received: 17 March 2009

Accepted: 6 May 2009

\begin{abstract}
Objective: The influence hemostatitc parameters on the morphological extent and severity of coronary artery disease were studied in patients with and without DM type 2.
\end{abstract}

Background: It is known that patients with diabetes (DM) have abnormal metabolic and hemostatic parameters

Methods: Of I 50 consecutive patients with angiographically proven coronary artery disease 29 presented with DM. Additionally to parameters of lipid-metabolism fibrinogen, tissueplasminogenactivator (t-PA), plasminogen-activator-inhibitor (PAI), plasmin-a-antiplasmin (PAP), prothrombin-fragment $\mathrm{I}+2(\mathrm{FI}+2)$, thrombin-antithrombin (TAT), von-willebrand-factor (vWF), platelet factor 4 (PF4), glykomembranproteine I40 (GMPI40) and the rheologic parameters plasma viscosity and red blood cell aggregation were evaluated. The extent and severity of CAD was evaluated according to the criteria of the American Heart Association.

Results: Patients with DM presented with a higher number of conventional risk factors as compared to non-diabetic patients. Additionally there were significant differences for $\mathrm{FI}+2$, red blood cell aggregation and PAI. Diabetic patients showed a more severe extent of coronary arteriosclerosis, which also could be found more distally. A significant relationship between bloodglucose, thrombocyte-activation (vWF), endogenous fibrinolysis (PAl) and the severity of CAD and a more distal location of stenoses could be found $(r=0.6, p<0.001)$.

Conclusion: Patients with coronary artery disease and DM type 2 showed marked alterations of metabolic, hemostatic, fibrinolytic and rheologic parameters, which can produce a prothrombogenic state. A direct association of thrombogenic factors on coronary morphology could be shown. This can be the pathophysiologic mechanism of more severe and distal pronounced coronary atherosclerosis in these patients. 


\section{Introduction}

Coronary artery disease is the essential cardiac manifestation of diabetes mellitus type 2 and is responsible for the predominant number of deaths. Early autopsy studies pointed out, that the morphological manifestation of coronary artery disease in patients with diabetes mellitus increases three to four times as compared with non-diabetics [1-3]. The clinical relevance of these results is documented by an increased incidence of cardiovascular events, and particularly in the "Framingham study" [4] and in the following epidemiological and longitudinal examinations $[5,6]$. The influence of diabetes mellitus is statistically independent of other established risk factors for the manifestation of coronary heart disease and is regarded as the risk factor with the highest predictive value for the incidence of cardiovascular complications

Since coronary thrombosis is essential for the pathogenesis of most acute coronary syndromes [7], the prothrombogenic constellation is probably of importance for the increased cardiovascular event rate among diabetics. Furthermore it seems likely, that subclinical intracoronary thrombi may promote atherosclerotic changes in patients with coronary heart disease [8].

During the last few years increased attention has been given to the complex metabolic changes associated with diabetes mellitus type 2 and insulin resistance. In this study, metabolic changes associated with diabetes, particularly changes of hemostasis and endogenous fibrinolysis were studied. The importance with regard to the incidence of cardiovascular events for diabetic patients was already proven in large epidemiological studies [9-14]; the direct association with morphological changes was not assessed yet.

In the present study we test the hypothesis that a) diabetic patients show a more diffuse form of coronary artery disease with a higher rate of distal stenosis and that b) haemostatic parameters correlate with the extent of coronary atherosclerosis in patients with diabetes mellitus type 2

\section{Patients, material and methods}

For this study 150 consecutive patients aged between 50 and 65 years, who were scheduled for elective coronary angiography, were recruited at Heinrich-Heine-University, Division of Cardiology. Unstable angina pectoris, acute myocardial infarction within the last six months before inclusion into the study, and prior coronary interventions were exclusion criteria. Furthermore, patients with acute or chronic infections and malignant diseases were excluded. Patients with a diabetes type 1 were not included in the study.

\section{Definition of cardiovascular risk factors}

Hyperlipidemia was defined as with total cholesterol above $220 \mathrm{mg} / \mathrm{dl}$, as triglycerides above $200 \mathrm{mg} / \mathrm{dl}$, with a positive history of hypercholesterolemia or hypertriglyceridemia and with lipid reducing therapies.

Diabetes was defined as fasting blood glucose above 126 $\mathrm{mg} / \mathrm{dl}$, or antidiabetic therapy. Hypertension was defined as resting blood pressure above $140 \mathrm{mmHg}$ systolic or 90 mmHg diastolic, or with antihypertensive medication. Nicotine consumption was assessed by patient history.

\section{Coronary Angiography}

In all patients coronary angiograms with imaging of the coronary arteries in different standardised projections were carried out. The degree of coronary artery stenosis was assessed by two experienced, independent examiners. The severity of CAD was defined as coronary 1, 2 or 3 vessel disease corresponding to the number of affected main vessels with hemodynamic relevant stenosis above $50 \%$. Extent of coronary atherosclerosis was determined by a special grading system in accordance with an evaluation system of the American Heart Association [15]. Based on these findings the coronary artery system was divided into 15 segments. The segment with a higher degree of stenosis got a higher score. The sum of these scores was divided by the number of judged segments. The result presents the extent of coronary atherosclerosis. To get information about the distribution pattern of coronary atherosclerosis a proximal score from the proximal segments of coronary main arteries and a distal score from the distal parts of main coronary arteries and vessels of first degree were calculated.

\section{Laborchemical methods}

Blood samples for the different parameters were taken at the day of cardiac catheterisation between 7:00 and 8:00 am after 30 minutes rest in a lying position. Venous puncture of an antecubital vene was done with a butterfly canula after a maximum venous compression time of 30 seconds and a maximum pressure of $40 \mathrm{mmHg}$. After decompression the first $4 \mathrm{ml}$ of blood were not used. For parameters of hemostasis and endogenous fibrinolysis vacutainer tubes with $0.129 \mathrm{M} \mathrm{Na}_{2}$ citrat were used. Tubes underwent centrifugation at $2000 \mathrm{~g}$ for 15 minutes. The plasma was taken and centrifugated at $2000 \mathrm{~g}$ for another 15 minutes. Samples were frozen at $-80^{\circ} \mathrm{C}$. The samples were analysed immediately after preparation from deeply frozen plasma within three months after sample taking.

Determination of plasma viscosity and red blood cell aggregation was performed from EDTA tubes within 4 hours after sample taking. Plasmaviscosity was deter- 
mined by the capillary tube viscosimeter of Rheomed, Aachen (Germany). For determination of red blood cell aggregation an erythrocyte aggregometer (Myrenne, Roetgen, Germany) was used.

Plasma fibrinogen levels were determined according to method described by Clauss [16]. Prothrombin fragment 1 and 2 were measured by Elisa. Specific activity of AT III was measured by a cinetic test; Protein $\mathrm{C}$ and $\mathrm{S}$ were measured by coagulometric tests. Determination of Plasminogenactivator inhibitor activity was performed by chromogenic enzymassay. Thrombin-Antithrombin III complex, plasma tissue plasminogenactivator antigen concentration, plasmin a2 antiplasmin and d-dimeres were determined by enzymimmunoassay.

\section{Obesity indices}

As a calculated index to estimate the extent of Obesity the "body mass index" is clinically established. This index calculates itself by the body weight $(\mathrm{kg})$ being divided by the square of the height $\left(\mathrm{m}^{2}\right)$. The relationship between waists and hip circumference forms another parameter for the classification of obesity [17]. This quotient was shown to correlate with the visceral fat mass [18].

\section{Statistical methods}

Statistical analyses were performed using SPSS software (Statistical Package for Social Sciences for Windows; SPSS
12.0, Munich). The results were tested for normal distribution by Kolmogoroff-Smirnoff test. For normally distributed parameters group comparison was made by use of paired and unpaired Student's t-test. Mann-Whitney UTest was used for non-normally distributed parameters. The Pearson correlation coefficient or the Spearman's rank correlation was used to describe the association between the variables in the study. A stepwise regression model was used to test the relationship of laboratory parameters on morphology. Chi square test was used for comparison of non-continuous data. Statistical significance was defined as $\mathrm{p}<0.05$.

\section{Results}

Out of 150 consecutive patients, 28 patients presented with the diagnosis of diabetes mellitus type 2 (19\%). Both groups showed a comparable age profile, they were not different with regard to height, however, diabetic patients were heavier, what resulted in a significantly higher "body mass index". Both waist circumference and the "Waist-to hip ratio" calculated from this differed significantly.

Diabetic patients showed a $20 \%$ higher rate of arterial hypertension (table 1). Other conventional risk factors did not differ between the groups (table 1). The laboratory evaluation showed that only HDL cholesterol differed significantly, although the differences for triglycerides are only not significantly different because of the wide stand-

Table I: Patient characteristics

\begin{tabular}{|c|c|c|c|c|}
\hline & $\begin{array}{l}\text { all patients } \\
(\mathrm{n}=150)\end{array}$ & $\begin{array}{l}\text { Diabetes mellitus Typ II } \\
\qquad(n=26)\end{array}$ & $\begin{array}{l}\text { control patients } \\
\quad(n=122)\end{array}$ & $\mathrm{p}$-value \\
\hline age (years) & $58 \pm 5$ & $57 \pm 4$ & $58 \pm 5$ & 0.1158 \\
\hline hypertension (\%) & $62.0 \%$ & $85.00 \%$ & $57.00 \%$ & 0.0076 \\
\hline hypercholesterinemia (\%) & $74.0 \%$ & $73.00 \%$ & $74.00 \%$ & 0.9419 \\
\hline hypertriglyceridemia(\%) & $40.0 \%$ & $46.00 \%$ & $39.00 \%$ & 0.47068 \\
\hline smoking (\%) & $10.0 \%$ & $4.00 \%$ & $11.00 \%$ & 0.28139 \\
\hline ex-smoking (\%) & $75.0 \%$ & $81.00 \%$ & $74.00 \%$ & 0.4543 \\
\hline history of vascular diesease (\%) & $31.0 \%$ & $39 \%$ & $30.00 \%$ & 0.37048 \\
\hline obesity (\%) & $83.0 \%$ & $100 \%$ & $80.00 \%$ & 0.01134 \\
\hline Hyperurikämie (\%) & $20.0 \%$ & $12 \%$ & $22.00 \%$ & 0.26987 \\
\hline total cholesterol $(\mathrm{mg} / \mathrm{dl})$ & $226 \pm 42$ & $225 \pm 50$ & $225 \pm 40$ & 0.5254 \\
\hline HDL - cholesterol (mg/dl) & $44 \pm 13$ & $37 \pm 10$ & $46 \pm 14$ & 0.0035 \\
\hline LDL - cholesterol (mg/dl) & $157 \pm 39$ & $159 \pm 45$ & $156 \pm 37$ & 0.9246 \\
\hline triglycerides $(\mathrm{mg} / \mathrm{dl})$ & $210 \pm 141$ & $239 \pm 189$ & $205 \pm 130$ & $0.468 I$ \\
\hline lipoprotein (a) (mg/dl) & $20,4 \pm 22,5$ & $16,1 \pm 21,9$ & $20,7 \pm 22,1$ & 0.1302 \\
\hline uric acid $(\mathrm{mg} / \mathrm{dl})$ & $6,3 \pm 1,5$ & $6,4 \pm 1,6$ & $5,6 \pm 1,1$ & 0.0341 \\
\hline fasting plasma glucose $(\mathrm{mg} / \mathrm{dl})$ & $|16 \pm 5|$ & $197 \pm 75$ & $100 \pm 19$ & 0.0001 \\
\hline Insuline $(\mathrm{mU} / \mathrm{l})$ & $8,8 \pm 5,7$ & $8,7 \pm 4,7$ & $8,8 \pm 5,9$ & 0.7382 \\
\hline $\mathrm{HbAlc}(\%)$ & $6,0 \pm 1,3$ & $8,1 \pm 1,5$ & $5,5 \pm 0,6$ & 0.0001 \\
\hline heigth & $174 \pm 6$ & $173 \pm 7$ & $174 \pm 6$ & 0.4923 \\
\hline weight $(\mathrm{kg})$ & $83 \pm 12$ & $85 \pm 10$ & $82 \pm 12$ & 0.171 \\
\hline Body-Mass-Index (kg/m2) & $27,35 \pm 3,42$ & $28,42 \pm 2,78$ & $27,12 \pm 3,51$ & 0.0367 \\
\hline Waist-to-Hip-Ratio & $0,99 \pm 0,07$ & $1,03 \pm 0,07$ & $0,98 \pm 0,07$ & 0.0035 \\
\hline waist circumference $(\mathrm{cm})$ & $99 \pm 9$ & $104 \pm 9$ & $100 \pm 6$ & 0.0079 \\
\hline hip circumference $(\mathrm{cm})$ & $100 \pm 6$ & $100 \pm 7$ & $100 \pm 6$ & 0.6175 \\
\hline
\end{tabular}


ard deviation (table 1). Parameters of glucose metabolism were markedly elevated in diabetic patients, as expected; there was no difference in fasting insulin levels.

Patients with diabetes mellitus type 2 showed higher values for fibrinogen, the difference, however, was not significant (table 2). Also, prothrombin fragments 1 and 2 as indicators for a thrombin synthesis and a marker for prothrombotic conditions, was elevated in patients with diabetes mellitus, although again, not significantly. Anthrombin III and D-dimer showed no statistical significant differences (table 2). Plasma viscosity and aggregation of erythrocytes as the essential variables influencing microcirculation were higher in patients with diabetes mellitus. Of the markers of fibrinolysis PAI activity was significantly higher in patients with diabetes. Thrombocytic parameters did not differ at all between the two groups.

Patients with diabetes more often presented with 3 vessel disease (table 2 ). The evaluated coronary score was signif- icantly higher in patients with than without diabetes mellitus. Patients with diabetes especially showed a higher distal score.

The plasma levels of insulin and HbA1c correlated on the one hand significantly with PAI activity and tPA concentration, on the other hand also with indices of obesity (table 3). Of the parameters of lipid metabolism only triglycerides correlated with insulin. Fasting glucose on the day of coronary angiography strongly correlated with the total and the distally weighted score $(\mathrm{R}=0.48$, table 3$)$.

We then calculated a univariant regression model for each of the three coronary scores and parameters of lipid and glucose metabolism, hemostasis and fibrinolysis, platelet activation, rheology, obesity and hypertension. Results are given in table 4. All significant parameters were included into a multivariate, stepwise regression analysis. This analysis revealed the most significant correlation between fasting glucose and all coronary scores but in particular with total and distal score, followed by waist to hip

Table 2: Parameters of hemostasis, rheology, fibrinolysis, platelet activation and extent and severity of coronary atherosclerosis

\begin{tabular}{|c|c|c|c|c|}
\hline & all patients & Diabetes mellitus Typ II & control patients & P-value \\
\hline & $(n=150)$ & $(n=26)$ & $(n=122)$ & \\
\hline \multicolumn{5}{|l|}{ hemostasis } \\
\hline fibrinogen (mg/dl) & $282 \pm 64$ & $295 \pm 76$ & $278 \pm 61$ & 0.1618 \\
\hline prothrombinfragment $\mathrm{I}+2(\mu \mathrm{g} / \mathrm{dl})$ & $0,99 \pm 0,52$ & $\mathrm{I}, 0 \mathrm{I} \pm 0,55$ & $0,87 \pm 0,37$ & 0.0622 \\
\hline D-Dimere $(\mu g / l)$ & $35 \pm 62$ & $31 \pm 43$ & $36 \pm 65$ & 0.5519 \\
\hline Thrombin-Antithrombin-Komplex $(\mu g / l)$ & $7,6 \pm 16$ & $9,6 \pm 18,7$ & $7,3 \pm 15,5$ & 0.5221 \\
\hline \multicolumn{5}{|l|}{ Rheology } \\
\hline plasma viscosity (mPas) & $1,30 \pm 0,09$ & $1,33 \pm 0,09$ & $1,29 \pm 0,09$ & 0.0933 \\
\hline erythocyte aggregation $M(E)$ & $6,3 \pm 1,8$ & $7,3 \pm 1,9$ & $6,1 \pm 1,8$ & 0.0026 \\
\hline erythocyte aggregation $\mathrm{MI}(\mathrm{E})$ & $11,3 \pm 2,5$ & $12,8 \pm 2,7$ & $11,0 \pm 2,3$ & 0.0013 \\
\hline hematocrit (\%) & $43,5 \pm 3,1$ & $42,7 \pm 3,7$ & $43,6 \pm 2,9$ & 0.1537 \\
\hline \multicolumn{5}{|l|}{ fibrinolysis } \\
\hline tissue-plasminogenaktivator (ng/dl) & $13,47 \pm 3,68$ & $14,18 \pm 3,36$ & $13,30 \pm 3,77$ & 0.4394 \\
\hline plasminogenactivatorinhibitor $(\mathrm{U} / \mathrm{ml})$ & $5,78 \pm 3,25$ & $7,36 \pm 3,24$ & $5,45 \pm 3,18$ & 0.0017 \\
\hline plasmin- $\alpha 2$-antiplasmin-complex $(\mu \mathrm{g} / \mathrm{dl})$ & $395 \pm 152$ & $378 \pm 168$ & $396 \pm 146$ & 0.4245 \\
\hline \multicolumn{5}{|l|}{ platelet activation } \\
\hline platelet count $(100.000 / \mathrm{ml})$ & $246 \pm 71$ & $265 \pm 71$ & $242 \pm 71$ & 0.1727 \\
\hline von Willebrand-factor $(\mu g / l)$ & $94 \pm 31$ & $99 \pm 32$ & $93 \pm 30$ & 0.3661 \\
\hline plateletfactor $4(\mu g / l)$ & $12,7 \pm 18,8$ & $9,2 \pm 10,9$ & $|3,4 \pm 20|$, & 0.9104 \\
\hline$\beta$-thromboglobulin $(\mu g / l)$ & $36,68 \pm 41,90$ & $30,07 \pm 17,57$ & $38,28 \pm 45,53$ & 0.7181 \\
\hline GMP I40 $(\mu \mathrm{g} / \mathrm{l})$ & $96,36 \pm 44,69$ & $94,64 \pm 23,41$ & $96,88 \pm 48,26$ & 0.2773 \\
\hline \multicolumn{5}{|l|}{ Extent and severity of coronary atherosclerosis } \\
\hline total score & $|, 45| \pm 0,59 \mid$ & $1,858 \pm 0,680$ & $1,379 \pm 0,550$ & 0.0182 \\
\hline proximal score & $1,399 \pm 0,696$ & $1,775 \pm 1,037$ & $1,333 \pm 0,607$ & 0.2363 \\
\hline distal score & $1,457 \pm 0,666$ & $1,874 \pm 0,647$ & $|, 388 \pm 0,65|$ & 0.0109 \\
\hline I-vessel CAD & $31.0 \%$ & $12.0 \%$ & $35.0 \%$ & \\
\hline 2-vessel CAD & $37.0 \%$ & $39.0 \%$ & $37.0 \%$ & \\
\hline 3-vessel CAD & $32.0 \%$ & $50.0 \%$ & $28.0 \%$ & 0.0306 \\
\hline
\end{tabular}


Table 3: The Pearson correlation coefficient or the Spearman's rank correlations were used to describe the association between the variables in the study.

\begin{tabular}{|c|c|c|c|c|c|c|c|c|}
\hline & tPA & PAI & cholesterol & $\mathrm{HDL}$ & LDL & $\operatorname{tg}$ & fibrinogen & plasmaviscosity \\
\hline \multirow[t]{2}{*}{ insuline } & 0.3173 & 0.2573 & 0.0112 & -0.152 & 0.0304 & 0.2702 & -0.0011 & 0.0444 \\
\hline & 0.008 & 0.002 & 0.896 & 0.076 & 0.725 & 0.001 & 0.99 & 0.612 \\
\hline \multirow[t]{3}{*}{ HbAlc } & 0.2941 & 0.4117 & & & & & & \\
\hline & 0.016 & 0.0001 & & & & & & \\
\hline & insuline & HbAlc & HDL & LDL & & & & \\
\hline \multirow[t]{2}{*}{ WHR } & 0.2716 & 0.2903 & -0.3765 & 0.3134 & & & & \\
\hline & 0.033 & 0.014 & 0.002 & 0.009 & & & & \\
\hline \multirow[t]{3}{*}{ C-Index } & 0.4067 & 0.4429 & -0.3539 & 0.1792 & & & & \\
\hline & 0.001 & 0.0001 & 0.004 & 0.153 & & & & \\
\hline & total score & prox. score & dist. score & & & & & \\
\hline \multirow[t]{2}{*}{ glucose } & 0.4872 & 0.2097 & 0.4769 & & & & & \\
\hline & 0.0001 & 0.108 & 0.4769 & & & & & \\
\hline
\end{tabular}

Upper line denotes $\mathrm{R}$, lower line the according $\mathrm{P}$-value

ratio and PAI activity for the distal score and von-willebrand factor for total score (table 4)

\section{Discussion}

\section{Coronary morphology in diabetes mellitus}

Although it is well established, that type 2 diabetes is a strong and independent risk factor for the development of atherosclerosis, there is much discussion about a "typical", diabetes related morphology of atherosclerosis. Many clinicians today believe, that diabetic patients present with more extensive atherosclerotic disease than non-diabetics. However, to our knowledge only very few studies confirm these subjective impressions, and these are mostly autopsy based. Early autopsy studies pointed out, that the morphological manifestation of coronary artery disease in patients with diabetes mellitus increases three to four times as compared with non-diabetics [1-3].

Here, we present a systematic approach to evaluate the coronary morphology of consecutive patients by angiography with regard to their diabetic status and can confirm this widespread belief. Coronary atherosclerosis can be found in more segments and is generally located more distally. This also confirms the results of a recent study, which could show a higher extent of coronary plaque burden in diabetic patients [19]. Recent studies using intravascular ultrasound (IVUS) to evaluate coronary plaque burden in diabetic patients could show more extensive atherosclerosis [20-22]. However, these studies are often technically limited and can not be used to assess distal segments. Nicholls and co-workers assessed IVUS and also quantitative coronary angiography (QCA) and could not find a correlation between diabetes and stenosis severity. However, QCA was only done in segments also evaluated by intravascular ultrasound and did only comprise the most severe stenosis per target vessel [22]. They did find diabetes to be a strong independent predictor of atherosclerotic coronary disease, but the distribution of atherosclerosis within the coronary arteries was not assessed. An analysis of pooled data revealed that coronary artery atherosclerosis in patients with diabetes mellitus is more extensive and accompanied by inadequate compensatory remodelling [23]. Additionally the progression of atheroma was more rapid in patients with diabetes, despite high use of well established and potent therapies. With this in mind angiographic assessment could underestimate the plaque burden. On the other hand recent studies suggest, that a high percentage of cardiac patients present with newly diagnosed type 2 diabetes by use of oral glucose tolerance tests (OGTT) [24-26]. OGTT was not part of this protocol; therefore the true rate of diabetes may be underestimated.

\section{Hemostasis and fibrinolysis in diabetes mellitus}

Type 2 diabetes mellitus, most often being part of a metabolic syndrome is closely associated with obesity, peripheral insulin resistance, arterial hypertension, hypercholesterinemia, hypertriglyceridemia and predisposes for atherosclerosis [27]. Peripheral insulin resistance is strongly associated with atherosclerosis, even after adjusting for other more conventional risk factors [28]. Whether this relation is causal, can only be suspected $[28,29]$, other authors discussed whether an impaired fibrinolysis could be the link to atherosclerosis [30].

The changes of hemostasis and endogenous fibrinolysis of diabetic patients in this study correspond with the literature $[9-13,30]$, although most often only single parameters were evaluated. These alterations might be responsible for higher atherogenicity and more cardiovascular events in a diabetic population. 
Table 4: univariant and multivariant (stepwise backward) regression model for each of the three coronary scores and parameters of lipid and glucose metabolism, hemostasis and fibrinolysis, platelet activation, rheology, obesity and hypertension.

\begin{tabular}{|c|c|c|c|c|c|c|c|c|}
\hline & \multicolumn{3}{|l|}{ total score } & \multicolumn{3}{|c|}{ distal score } & \multicolumn{2}{|c|}{ proximal score } \\
\hline & $\begin{array}{c}\text { Univariat } \\
\quad \mathrm{R}\end{array}$ & $\mathrm{p}$-value & Multivariat & $\begin{array}{c}\text { Univariat } \\
\text { R }\end{array}$ & $\mathrm{p}$-value & $\begin{array}{c}\text { Multivariat } \\
\mathrm{p} \text {-value }\end{array}$ & $\begin{array}{c}\text { Univariant } \\
\quad \mathrm{R}\end{array}$ & p-value \\
\hline \multicolumn{9}{|l|}{ Conventional risk factors } \\
\hline Total cholesterol (mg/dl) & 0,17099 & 0,1665 & & 0,15137 & 0,2214 & & 0,12198 & 0,3254 \\
\hline HDL - cholesterol (mg/dl) & 0,1864 & 0,134 & & 0,21858 & 0,0779 & 0,3475 & 0,02781 & 0,8246 \\
\hline LDL - cholesterol (mg/dl) & 0,11409 & 0,3617 & & 0,08219 & 0,5118 & & 0,11332 & 0,365 \\
\hline Triglycerides (mg/dl) & 0,00269 & 0,9827 & & 0,00918 & 0,9412 & & 0,02211 & 0,8591 \\
\hline Uric acid (mg/dl) & 0,28913 & 0,0205 & 0,2187 & 0,28087 & 0,0246 & 0,1682 & 0,16794 & 0,2011 \\
\hline Plasma glucose (mg/dl) & 0,5456 & 0,0001 & 0,0001 & 0,47045 & 0,0001 & 0,0001 & 0,42108 & 0,0005 \\
\hline Insuline $(\mathrm{mU} / \mathrm{l})$ & 0,01736 & 0,8943 & & 0,01917 & 0,8834 & & 0,10553 & 0,4182 \\
\hline $\mathrm{HbAlc}(\%)$ & 0,13988 & 0,2589 & & 0,14837 & 0,2308 & & 0,02186 & 0,8606 \\
\hline \multicolumn{9}{|l|}{ Hemostasis } \\
\hline Fibrinogen $(\mathrm{mg} / \mathrm{dl})$ & 0,07329 & 0,5556 & & 0,07759 & 0,5326 & & 0,03252 & 0,7939 \\
\hline Prothrombinfragment I+ $2(\mu \mathrm{g} / \mathrm{l})$ & 0,05127 & 0,6803 & & 0,05278 & 0,6715 & & 0,00098 & 0,9937 \\
\hline D-dimers $(\mu g / l)$ & 0,22375 & 0,0687 & & 0,19556 & 0,1127 & & 0,19572 & 0,1124 \\
\hline Thrombin-Antithrombin-complex & 0,11095 & 0,3714 & & 0,10142 & $0,4|4|$ & & 0,07338 & 0,5551 \\
\hline tissue-Plasminogenactivator (ng/dl) & 0,09567 & 0,4913 & & 0,07875 & $0,57 \mid 4$ & & 0,08 & 0,5653 \\
\hline Plasminogenactivatorinhibitor (U/ml) & 0,22549 & 0,0666 & 0,1947 & 0,25669 & 0,036 & 0,0407 & 0,03477 & 0,78 \\
\hline Plasmin-a2-Antiplasmin-complex ( $\mu \mathrm{g} / \mathrm{dl})$ & 0,08721 & 0,4828 & & $0,086 \mid 4$ & 0,4882 & & 0,05627 & 0,6511 \\
\hline \multicolumn{9}{|l|}{ Platelet parameters } \\
\hline von Willebrand-Factor $(\mu \mathrm{g} / \mathrm{l})$ & 0,3335 & 0,0058 & 0,013 & 0,32558 & 0,0072 & 0,2661 & 0,2229 & 0,698 \\
\hline Platelet factor $4(\mu \mathrm{g} / \mathrm{l})$ & 0,00077 & 0,9951 & & 0,02395 & 0,8486 & & 0,6825 & 0,5861 \\
\hline$\beta$-Thromboglobulin $(\mu \mathrm{g} / \mathrm{l})$ & 0,08704 & 0,487 I & & 0,05816 & 0,6428 & & 0,11954 & 0,339 \\
\hline GMP I40 ( $\mu \mathrm{g} / \mathrm{I})$ & 0,11087 & 0,3718 & & 0,10535 & 0,3962 & & 0,07522 & 0,5452 \\
\hline \multicolumn{9}{|l|}{ Rheological parameters } \\
\hline Plasma viscosity (mPas) & 0,05615 & 0,6518 & & 0,07809 & 0,5299 & & 0,0132 & 0,9156 \\
\hline Erythrocyte aggregation M (E) & 0,00747 & 0,9552 & & 0,02073 & 0,8761 & & 0,02058 & 0,877 I \\
\hline Erythrocyte aggregation MI (E) & 0,02564 & $0,847 \mid$ & & 0,04427 & 0,7392 & & 0,034 & 0,7982 \\
\hline \multicolumn{9}{|l|}{ Obesitys-Indices } \\
\hline BMI $\left(\mathrm{kg} / \mathrm{m}^{2}\right)$ & 0,07228 & 0,561 & & 0,06516 & 0,6003 & & 0,06279 & 0,6137 \\
\hline WHR & 0,18316 & 0,165 & & $0,24 \mid 49$ & 0,0654 & 0,0003 & 0,00075 & 0,9955 \\
\hline Waist (cm) & 0,02086 & 0,8799 & & 0,01037 & 0,9401 & & 0,05692 & 0,6798 \\
\hline $\mathrm{Hip}(\mathrm{cm})$ & 0,00135 & 0,9922 & & 0,00294 & 0,983 & & 0,02922 & 0,8323 \\
\hline \multicolumn{9}{|l|}{ Blood pressure } \\
\hline systolic (mm Hg) & 0,14903 & 0,2287 & & 0,14472 & 0,2426 & & 0,10775 & 0,3855 \\
\hline diastolic (mm Hg) & 0,10406 & 0,402 & & 0,05629 & 0,6509 & & 0,16688 & $0,|77|$ \\
\hline mean $(\mathrm{mm} \mathrm{Hg})$ & 0,1775 & 0,1507 & & $0,|386|$ & 0,2633 & & 0,19968 & 0,1052 \\
\hline
\end{tabular}

We showed, that plasminogen activator inhibitor activity (PAI) was increased in diabetic patients; this corresponds to other studies $[12,14,31,32]$. Additionally we found a strong correlation between PAI and insulin levels, which confirms results from experimental studies, where insulin decreased PAI activity in a dose dependent manner $[12,33]$.

The potential role of insulin as one of the mechanisms in atherogenesis in diabetic patients has been discussed for
25 years [34]. Results of various prospective studies indicated that elevated plasma insulin levels cause and enhance atherosclerosis [35-37]. Diverse diseases associated with hyperinsulinemia show an early and extended manifestation of atherosclerosis [38-43]. Several studies proved that elevated insulin levels are accompanied by reduced endogenous fibrinolysis $[12,14,31]$. On the one hand hyperinsulinemia is associated with a decreased t-PA concentration [11], on the other hand it causes an increase of PAI activity [12-14,31]. 
The importance of PAI is underlined by a follow up study of men after primary myocardial infarction. Those patients who showed elevated PAI concentrations as a sign of reduced fibrinolysis were at increased risk of reinfarction [44,45]. High concentrations of von Willebrand factor antigen are supposed to be markers of endothelial lesions and present a procoagulative mechanism due to an enhanced platelet adhesion [46].

The question remains, how does diabetes mediate its specific effects towards a diabetic specific morphology? Some authors suggest that diabetics undergo invasive evaluation later than others due to their cardiac neuropathy and the resulting lack of symptoms, others, that the impact of the often combined risk factors (e.g. hypertension, high LDL etc.) may trigger an accelerated form of atherosclerosis. This study extends these views by showing a close association between coronary morphology and a diabetic status with alterations of haemostasis and fibrinolysis, especially for distal coronary artery disease. Univariate and multivariate regression analysis revealed a strong relationship between the extent of coronary and especially distal coronary atherosclerosis and fasting glucose, PAI-1 and vonWillebrand-factor.

\section{Conclusion}

Both parameters of endogenous fibrinolysis and markers of platelet activity showed a relevant association on the extent of coronary atherosclerosis. This association applied to both the total and in particular to the distally weighted coronary atherosclerosis score. Additional predisposing factors were increased uric acid and glucose concentrations as well as the "Waist hip ratio". These changes are part of the "metabolic syndrome" describing obesity, arterial hypertension and typical changes of glucose and lipid metabolism, hemostasis and fibrinolysis.

The metabolic changes with imbalance of platelet activity, hemostasis and endogenous fibrinolysis, and rheology favour a prothrombotic milieu. These systemic changes may result in an increased, thrombosis driven atherosclerotic process, in part explaining the advanced coronary plaque burden and in particular the more distal pronounced distribution of coronary atherosclerosis in patients with diabetes. More research is needed to elucidate these potential mechanisms and possibly develop a tailored therapy for these diabetes specific mechanisms of atherothrombotic disease.

\section{Competing interests}

The authors declare that they have no competing interests.

\section{Authors' contributions}

TJ participated in the design and coordinated the study, performed the statistical analysis and drafted the manu- script. AP coordinated the study, and drafted the manuscript. GP coordinated the study and drafted the manuscript. FS participated in the design and coordinated the study, and drafted the manuscript. All authors read and approved the final manuscript.

\section{References}

I. Kessler II: Mortality experience of diabetic patients. A twentysix-year follow-up study. Am J Med 197I, 5 1:715-724.

2. Root HF, Bland EF, Gordon WH, White PW: Coronary arteriosclerosis in diabetes mellitus. JAMA 1939, I | 8:27-30.

3. Stearns S, Schlesinger MJ, Rudy A: Incidence and clinical significance of coronary artery disease in diabetes mellitus. Archives of Internal Medicine 1947, 80:463.

4. Garcia MJ, McNamara PM, Gordon T, Kannel WB: Morbidity and mortality in diabetics in the Framingham population. Sixteen year follow-up study. Diabetes 1974, 23:105-III.

5. Huxley R, Barzi F, Woodward M: Excess risk of fatal coronary heart disease associated with diabetes in men and women: meta-analysis of 37 prospective cohort studies. BMJ 2006, 332(7533):73-8.

6. Kannel WB, McGee DL: Diabetes and cardiovascular disease. The Framingham study. JAMA 1979, 24I:2035-2038.

7. Fuster V, Badimon L, Badimon JJ, Chesebro JH: The pathogenesis of coronary artery disease and the acute coronary syndromes (2). $N$ Engl] Med 1992, 326:310-318.

8. Schoebel FC, Gradaus F, Jax TW, Stiegler HM, Stein DA, Borries M, Kelm M, Strauer BE, Leschke M: Die Bedeutung der Koronarthrombose für die chronsiche Myokardischämie. Z Kardiol 1997, 86(SuppI I):7I-83.

9. Thompson SG, Kienast J, Pyke SD, Haverkate F, Loo JC van de: Hemostatic factors and the risk of myocardial infarction or sudden death in patients with angina pectoris. European Concerted Action on Thrombosis and Disabilities Angina Pectoris Study Group [see comments]. N Engl J Med 1995, 332:635-64I.

10. Agewall S, Fagerberg B, Attvall S, Ljungman S, Urbanavicius V, Tengborn L, Wikstrand J: Microalbuminuria, insulin sensitivity and haemostatic factors in non-diabetic treated hypertensive men. Risk Factor Intervention Study Group. J Intern Med I 995 , 237:195-203.

II. Eliasson M, Asplund K, Evrin PE, Lindahl B, Lundblad D: Hyperinsulinemia predicts low tissue plasminogen activator activity in a healthy population: the Northern Sweden MONICA Study. Metabolism 1994, 43: I579-1586.

12. Nordt TK, Sawa H, Fujii S, Sobel BE: Induction of plasminogen activator inhibitor type-I (PAI-I) by proinsulin and insulin in vivo. Circulation 1995, 91:764-770.

13. Fisher BM, Quin JD, Rumley A, Lennie SE, Small M, MacCuish AC, Lowe GD: Effects of acute insulin-induced hypoglycaemia on haemostasis, fibrinolysis and haemorheology in insulindependent diabetic patients and control subjects. Clin Sci Colch 1991, 80:525-531.

14. Auwerx J, Bouillon R, Collen D, Geboers J: Tissue-type plasminogen activator antigen and plasminogen activator inhibitor in diabetes mellitus. Arteriosclerosis. 1988, 8(I):68-72.

15. Austen WG, Edwards JE, Frye RL, Gensini GG, Gott VL, Griffith LS, McGoon DC, Murphy ML, Roe BB: A reporting system on patients evaluated for coronary artery disease. Report of the Ad Hoc Committee for Grading of Coronary Artery Disease, Council on Cardiovascular Surgery, American Heart Association. Circulation 1975, 5 I (Suppl):5-40.

16. Clauss A: Gerinnungsphysiologische Schnellmethode zur Bestimmung des Fibrinogens. Acta Haematol 1957, 17:237-24I.

17. Kissebah AH, Vydelingum N, Murray R, Evans D, Hartz A, Kalkhoff RK, Adams PW: Relationship of body fat distribution to metabolic complication of obesity. J Endocrinol Metab 1982, 54:254-260.

18. Ashwell M, Cole TJ, Dixon AK: Obesity: new insights into the anthropometric classification of fat distribution shown by computed tomography. $\mathrm{Br}$ Med J 1985, 290:1692-1694.

19. Schukro C, Syeda B, Yahya N, Gessl A, Holy EW, Pichler P, Derntl M, Glogar D: Volumetric intravascular ultrasound imaging to 
illustrate the extent of coronary plaque burden in type 2 diabetic patients. J Diabetes Complications 2007, 2I(6):38I-6.

20. Larsen JR, Tsunoda T, Tuzcu EM, Schoenhagen P, Brekke M, Arnesen $\mathrm{H}$, Hanssen KF, Nissen SE, Dahl-Jorgensen K: Intracoronary ultrasound examinations reveal significantly more advanced coronary atherosclerosis in people with type I diabetes than in age- and sex-matched non-diabetic controls. Diab Vasc Dis Res 2007, 4(I):62-5.

21. Nasu K, Tsuchikane E, Katoh O, Fujita H, Surmely JF, Ehara M, Kinoshita Y, Tanaka N, Matsubara T, Asakura Y, Asakura K, Terashima M, Suzuki T: Plaque characterisation by Virtual Histology intravascular ultrasound analysis in patients with type 2 diabetes. Heart 2008, 94(4):429-33.

22. Nicholls SJ, Tuzcu EM, Crowe T, Sipahi I, Schoenhagen P, Kapadia S, Hazen SL, Wun CC, Norton M, Ntanios F, Nissen SE: Relationship between cardiovascular risk factors and atherosclerotic disease burden measured by intravascular ultrasound. J Am Coll Cardiol 2006, 47(10): 1967-75.

23. Nicholls SJ, Tuzcu EM, Kalidindi S, Wolski K, Moon KW, Sipahi I, Schoenhagen $\mathrm{P}$, Nissen SE: Effect of diabetes on progression of coronary atherosclerosis and arterial remodeling: a pooled analysis of $\mathbf{5}$ intravascular ultrasound trials. J Am Coll Cardio 2008, 52(4):255-62.

24. Norhammar A, Tenerz A, Nilsson G, Hamsten A, Efendíc S, Rydén L, Malmberg K: Glucose metabolism in patients with acute myocardial infarction and no previous diagnosis of diabetes mellitus: a prospective study. Lancet 2002, 359(9324):2। 40-4.

25. Lankisch M, Füth R, Gülker H, Lapp H, Bufe A, Haastert B, Martin S, Rathmann W: Screening for undiagnosed diabetes in patients with acute myocardial infarction. Clin Res Cardiol 2008, 97(10):753-9.

26. Lankisch M, Füth R, Schotes D, Rose B, Lapp H, Rathmann W, Haastert B, Gülker H, Scherbaum WA, Martin S: High prevalence of undiagnosed impaired glucose regulation and diabetes mellitus in patients scheduled for an elective coronary angiography. Clin Res Cardiol 2006, 95(2):80-7.

27. Taegtmeyer $\mathrm{H}$ : Insulin resistance and atherosclerosis. Com mon roots for two common diseases? Circulation 1996, 93:1777-1779.

28. Howard G, O'Leary DH, Zaccaro D, Haffner S, Rewers M, Hamman $R$, Selby JV, Saad MF, Savage P, Bergman R: Insulin sensitivity and atherosclerosis. The Insulin Resistance Atherosclerosis Study (IRAS) Investigators [see comments]. Circulation 1996, 93:1809-1817.

29. DeFronzo RA, Ferrannini E: Insulin resistance. A multifaceted syndrome responsible for NIDDM, obesity, hypertension, dyslipidemia, and atherosclerotic cardiovascular disease. Diabetes Care 1991, 14:173-194.

30. Juhan Vague I, Alessi MC, Vague P: Increased plasma plasminogen activator inhibitor I levels. A possible link between insulin resistance and atherothrombosis. Diabetologia 1991, 34:457-462.

31. Juhan Vague I, Alessi MC: Plasminogen activator inhibitor I and atherothrombosis. Thromb Haemost 1993, 70: I38-143.

32. Juhan Vague I, Roul C, Alessi MC, Ardissone JP, Heim M, Vague P: Increased plasminogen activator inhibitor activity in non insulin dependent diabetic patients - relationship with plasma insulin. Thromb Haemost 1989, 61:370-373.

33. McGill JB, Schneider DJ, Arfken CL, Lucore CL, Sobel BE: Factors responsible for impaired fibrinolysis in obese subjects and NIDDM patients. Diabetes 1994, 43: 104-109.

34. Stout RW: Insulin and atherosclerosis. Lancet 1969, 2:327-328.

35. Pyorala K: Diabetes and coronary heart disease. Acta Endocrinol Suppl Copenh 1985, 272:

36. Cullen K, Stenhouse NS, Wearne KL, Welborn TA: Multiple regression analysis of risk factors for cardiovascular disease and cancer mortality in Busselton, Western Australia - 13year study. J Chronic Dis 1983, 36:37I-377.

37. Fontbonne A, Tchobroutsky G, Eschwege E, Richards JL, Claude JR, Rosselin GE: Coronary heart disease mortality risk: plasma insulin level is a more sensitive marker than hypertension or abnormal glucose tolerance in overweight males. The Paris Prospective Study. Int J Obes 1988, 12:557-565.

38. Swislocki AL, Hoffman BB, Reaven GM: Insulin resistance, glucose intolerance and hyperinsulinemia in patients with hypertension. Am J Hypertens 1989, 2:419-423.
39. Singer P, Godicke W, Voigt S, Hajdu I, Weiss M: Postprandial hyperinsulinemia in patients with mild essential hypertension. Hypertension 1985, 7:182-186.

40. DeFronzo RA: Insulin secretion, insulin resistance, and obesity. Int J Obes 1982, 6(SuppI I):73-82.

41. Modan M, Halkin H, Almog S, Lusky A, Eshkol A, Shefi M, Shitrit A Fuchs Z: Hyperinsulinemia. A link between hypertension obesity and glucose intolerance. J Clin lnvest 1985, 75:809-8I7.

42. Grundy SM: Hypertriglyceridemia: mechanisms, clinical significance, and treatment. Med Clin North Am 1982, 66:519-535.

43. Orchard TJ, Becker DJ, Bates M, Kuller LH, Drash AL: Plasma insulin and lipoprotein concentrations: an atherogenic association? Am J Epidemiol 1983, I I 8:326-337.

44. Hamsten A, de Faire U, Walldius G, Dahlen G, Szamosi A, Landou C, Blomback M, Wiman B: Plasminogen activator inhibitor in plasma: risk factor for recurrent myocardial infarction. Lancet 1987, 2:3-9.

45. Hamsten A, Wiman B, de Faire U, Blomback M: Increased plasma levels of a rapid inhibitor of tissue plasminogen activator in young survivors of myocardial infarction. N Engl J Med 1985, 3 | 3:1557-1563.

46. Jansson $\mathrm{JH}$, Nilsson TK, Johnson $\mathrm{O}$ : von Willebrand factor in plasma: a novel risk factor for recurrent myocardial infarction and death [see comments]. Br Heart J 199I, 66:35I-355.
Publish with Biomed Central and every scientist can read your work free of charge

"BioMed Central will be the most significant development for disseminating the results of biomedical research in our lifetime. "

Sir Paul Nurse, Cancer Research UK

Your research papers will be:

- available free of charge to the entire biomedical community

- peer reviewed and published immediately upon acceptance

- cited in PubMed and archived on PubMed Central

-yours - you keep the copyright
BioMedcentral 